\title{
ENFORCEMENT OF ENVIRONMENTAL PROTECTION LAWS UNDER COMMUNISM AND DEMOCRACY*
}

\author{
DIETRICH EARNHART \\ University of Kansas
}

\begin{abstract}
Lax enforcement of environmental protection laws in the formerly communist countries of Eastern and Central Europe is offered as one contributing factor to the large-scale environmental degradation that these countries have experienced. This article empirically examines enforcement responses to water-damaging "accidents" (for example, an oil spill) in the Czech Republic for the years 1988-92, a time period that spans both the communist political regime and the democratic political regime. In particular, it focuses on ex post penalties: required remediation (for example, cleanup after an oil spill) and monetary fines. Empirical analysis reveals the factors driving enforcement strategies in each political period and contrasts their influence under the two regimes. In particular, it identifies the operative liability rules guiding remediation and monetary fine decisions.
\end{abstract}

\section{INTRODUCTION}

$\mathrm{R}$ ECENT economic analyses address the poor environmental conditions in the transitional countries of Central and Eastern Europe. ${ }^{1}$ Various reasons for the environmental degradation experienced by these countries under communist rule have been offered: heavy emphasis on pollution-intensive

\footnotetext{
* I would like to thank Martin David for his invaluable advice, insight, and support. My research has also improved from suggestions offered by Kathleen Segerson, Jim Andreoni, Avery Katz, Kathryn Spier, Dan Bromley, Arik Levinson, participants of the Public Workshop at the University of Wisconsin-Madison, and discussants at the Association of Environmental and Resource Economists annual meetings. Tomaš Jelínek provided excellent research assistance. Financial support of my research in the Czech Republic was given by the University of Pittsburgh, the Center for Economic Research and Graduate Education (CERGE), and the United States Agency for International Development (US AID). Last, I am deeply indebted to Daniel Půlpán of the Czech Inspection-Water Management Division. Needless to say, the material presented here represents only my viewpoint.

${ }^{1}$ For example, see Gordon Hughes, Are the Costs of Cleaning Up Eastern Europe Exaggerated? Economic Reform and the Environment, 7 Oxford Rev Econ Pol 106 (1992); Alan Krupnick, Ken Harrison, Eric Nickell, and Michael Toman, The Value of Health Benefits from Ambient Air Quality Improvements in Central and Eastern Europe: An Exercise in Benefits Transfer, 7 Envir \& Resource Econ 307 (1996); K. Hubbard and T. Selden, Environmental Failures of Central Planning, 7 Socy \& Natural Resources 169 (1994).
}

[Journal of Law and Economics, vol. XL (October 1997)]

(C) 1997 by The University of Chicago. All rights reserved. 0022-2186/97/4002-0004\$01.50 
industries, subsidized energy prices that encouraged high rates of energy consumption, lack of advanced pollution control technologies, and weak enforcement of protection laws.

Informal studies provide anecdotal evidence of the weak enforcement of environmental protection laws in these formerly communist countries. ${ }^{2}$ However, no formal studies analyze enforcement under communism or during the rise of capitalism. As an attempt to address this issue, this article examines the enforcement of water protection laws in the Czech Republic during the years 1988-92. This time period spans both politicoeconomic systems given that the Czechoslovak communist regime collapsed in November 1989. In particular, this article analyzes enforcement actions taken in response to water-damaging "accidents" (for example, an oil spill), ${ }^{3}$ focusing on ex post penalties: required remediation (for example, cleanup of a body of water damaged by an oil spill) and monetary fines. From a more conceptual framework, these enforcement actions can be regarded as government steps to control stochastic externalities. ${ }^{4}$

Water protection in the Czech Republic offers an excellent opportunity to examine possibly different enforcement strategies prompted by unprecedented political changes. Although water protection laws changed very little during the period considered, the priority given to environmental protection dramatically changed from the communist regime to the democratic regime. While the communist regime overtly suppressed information on environmental conditions, the democratic regime on ascendance immediately released environmental information and took steps to improve environmental conditions. ${ }^{5}$ Most relevant to this study, the democratic regime declared its intentions to increase the enforcement of existing water protection laws.

To capture water protection efforts in the Czech Republic, this study exploits very unique and incredibly rich data. Since 1988, the main enforcer of water laws-Czech Water Inspection-has maintained a database on all observed water-damaging accidents. In addition to information on imposed penalties, this database includes extensive details on each accident: date,

\footnotetext{
${ }^{2}$ For example, see World Bank, 1-2 Czech and Slovak Federal Republic Joint Environmental Study (1992).

${ }^{3}$ Of course, some of these events may have not been accidental but instead quite intentional. The distinction does not disrupt this analysis because it seeks to explain government reactions, not polluters' motives.

${ }^{4}$ For example, see Steven Shavell, Risk-Sharing and Incentives in the Principal and Agent Relationship, 10 Bell J Econ 55 (1979); Mark Cohen, Optimal Enforcement Strategy to Prevent Oil Spills: An Application of a Principal-Agent Model with Moral Hazard, 30 J Law \& Econ 23 (1987).

${ }^{5}$ Czech Ministry of the Environment, Environment of the Czech Republic: Evolution, Situations, and Trends to the End of 1989 (1990).
} 
location, cause, type of contaminant, economic classification of the responsible party, and any resulting damages (if measured). To complement this database, the author gathered much institutional information by analyzing all relevant Czech water laws and interviewing numerous Czech environmental authorities and legal experts.

With a focus on the (possibly) different enforcement strategies implemented under the two political regimes, the thrust of this article is to identify the driving factors behind penalty decisions during each political period and to contrast the factors' influences in the two political periods. Estimation results show that enforcement strategies significantly differ between the two political regimes, while many aspects remain similar across the entire period considered. The most interesting result is the strong effect of political influence on penalty decisions, especially under communism. Most noticeable is the preferential treatment granted to military and foreign entities and the diminished preference shown during the democratic period. The greater importance of political influence in the communist period is consistent with the potential for and reliance on political maneuvering in that period.

This empirical analysis represents not only the first research on efforts to enforce environmental protection laws in the transitional countries of Central and Eastern Europe but one of the few empirical analyses of enforcement in any context. Although the law and economics literature provides much conceptual work on enforcement and the use of penalties, ${ }^{6}$ there exists a relative dearth of empirical work on these issues, especially in the environmental area. Analyses by Mark Cohen and Mary Deily and Wayne Gray stand out as the only empirical analyses of environmental enforcement. ${ }^{7,8}$

${ }^{6}$ For example, see Gary Becker, Crime and Punishment: An Economic Analysis, $78 \mathrm{~J}$ Pol Econ 526 (1968); Steven Shavell, Economic Analysis of Accident Law (1987); Mitchell Polinsky and Steven Shavell, Enforcement Costs and the Optimal Magnitude and Probability of Fines, 35 J Law \& Econ 133 (1992).

${ }^{7}$ Cohen (cited in note 4); Mark Cohen, Environmental Crime and Punishment: Legal/ Economic Theory and Empirical Evidence on Enforcement of Federal Environmental Statutes, 82 J Crim L \& Criminol 1054 (1992); Mary Deily and Wayne Gray, Enforcement of Pollution Regulations in a Declining Industry, 21 J Envir Econ \& Mgmt 260 (1991).

${ }^{8}$ Empirical analyses of general enforcement decisions are limited to the following research: Mark Cohen, The Motives of Judges: Empirical Evidence from Antitrust Sentencing, 12 Intl Rev L \& Econ 12 (1992); J. Finsinger, T. Hoehn, and A. Pototschnig, The Enforcement of Product Liability Rules: A Two-Country Analysis of Court Cases, 11 Intl Rev L \& Econ 133 (1991); John Nash, To Make the Punishment Fit the Crime: A Theory and Statistical Estimation of A Multi-Period Optimal Deterrence Model, 11 Intl Rev L \& Econ 101 (1991); Edward Snyder, The Effect of Higher Criminal Penalties on Antitrust Enforcement, 33 J Law \& Econ 439 (1990); Malcolm Coate and Fred McChesney, Empirical Evidence on FTC Enforcement of the Merger Guidelines, 30 Econ Inquiry 277 (1992). 
The rest of this article is organized as follows. Section II depicts the two political regimes' attitudes toward environmental protection. Section III portrays the application of the principal-agent model to the enforcement of water protection laws. Section IV describes the Czech enforcement responses to water-damaging accidents and the database on accidents. Section $\mathrm{V}$ provides econometric analysis of actual enforcement actions taken in response to accidents and identifies the driving factors behind these enforcement actions. Section VI summarizes the results.

\section{Water and Enforcement in the CZech Republic}

\section{A. Political Regimes and Water Protection Enforcement}

When examining Czech government efforts to enforce water protection laws in the Czech Republic, two key institutional details prove critical. First, the legal framework surrounding water protection changed very little during the period 1988-92. Second, the prominence of environmental protection as a government concern was dramatically different under the communist and democratic regimes: "For more than 40 years, the two republics of Czechoslovakia made minimal efforts to protect the environment." As evidence of this disregard, the communist government granted priority to economic interests over the environment. ${ }^{10}$ Yet Czechoslovak citizens had little opportunity to increase environmental protection efforts because information on the environment was suppressed, as was most environmental dissidence. ${ }^{11,12}$

For these and other reasons, the former Czechoslovakia now suffers "severe human and ecological health problems" 13 and had acquired the second worst environmental quality in Europe by $1989 .{ }^{14}$ As a matter of fact, 83 percent of Czech inhabitants considered the environment of their living quarters to be unsatisfactory. ${ }^{15}$ Eventually, the Czech ecological crisis

${ }^{9}$ World Bank (cited in note 2).

${ }^{10}$ Czech Ministry of the Environment (cited in note 5).

"Id.

${ }^{12}$ Nevertheless, citizens did participate in the enforcement of water protection laws. For details on the phenomenon of water-related citizen correspondence, see Dietrich Earnhart, Public Influence on Environmental Protection Efforts: Water-Related Citizen Correspondence in the Czech Republic (unpublished manuscript, Univ Wisconsin-Madison, 1995).

${ }^{13}$ World Bank (cited in note 2).

${ }^{14}$ Czech Ministry of the Environment (cited in note 5).

${ }^{15}$ Czech Ministry of the Environment, Environment of the Czech Republic: State of the Environment (1992). 
caused a loss of confidence in the communist regime and helped precipitate the 1989 Velvet Revolution that toppled the regime. ${ }^{16}$

Once the communist regime collapsed, environmental leaders joined in creating the new government, particularly the environmental ministries, ${ }^{17}$ and the new democratic regime began taking steps to improve environmental conditions. Since 1990, the Czech government has been making "conscientious efforts to institute environmental regulations that comply with international standards, especially those of the European Community to which it has applied for full membership." 18 Most important, the new government announced its intentions to increase "enforcement of existing laws considered to be sufficient," such as water protection laws. ${ }^{19}$

The stark contrast of government priorities toward water quality protection between the two Czech political regimes offers an excellent opportunity to examine the different enforcement policies implemented in the transitional countries of Central and Eastern Europe.

\section{B. Legal Efforts to Protect Water Quality from Water-Damaging Accidents}

In addition to other sources, water quality in the Czech Republic has been significantly degraded by water-damaging accidents. ${ }^{20}$ Figure 1 shows the annual number of water-damaging accidents during the period 198192. Since the end of communist rule in 1989, the number of accidents has steadily declined. Certainly, the substantial decline in economic activity during this period-real gross national product declined 20.7 percent between 1989 and 1992 - may explain much of this drop. Moreover, increased enforcement may have begun to deter polluters from causing accidents, as suggested by the Czech Ministry of the Environment. ${ }^{21,22}$

${ }^{16}$ Czech Ministry of the Environment (cited in note 5).

17 Tom Atlee, Notes on Czechoslovakian Grassroots Activism: Findings and Recommendations (unpublished manuscript, Czechoslovak Federal Ministry for the Environment, 1991).

18 Ana Goshko, The Czech and Slovak Federal Republic in Transition (Congressional Research Service Report for Congress No. 92-52F December 1991).

19 David Hunter and Margaret Bowman, An Overview of the Environmental Community in the Czech and Slovak Federal Republic (unpublished manuscript, Center for International Environmental L, 1991).

2) Czech Ministry of the Environment (cited in note 5).

21 Czech Ministry of the Environment (cited in note 15).

${ }^{22}$ Following 1986, the number of accidents leapt. Unfortunately, I can provide no good explanation for this drastic change. One possible explanation is a break in the series according to a change in the reporting procedures. Since the empirical analysis covers only the years 1988-92, any potential reporting change between 1986 and 1987 would not affect the empirical results. 


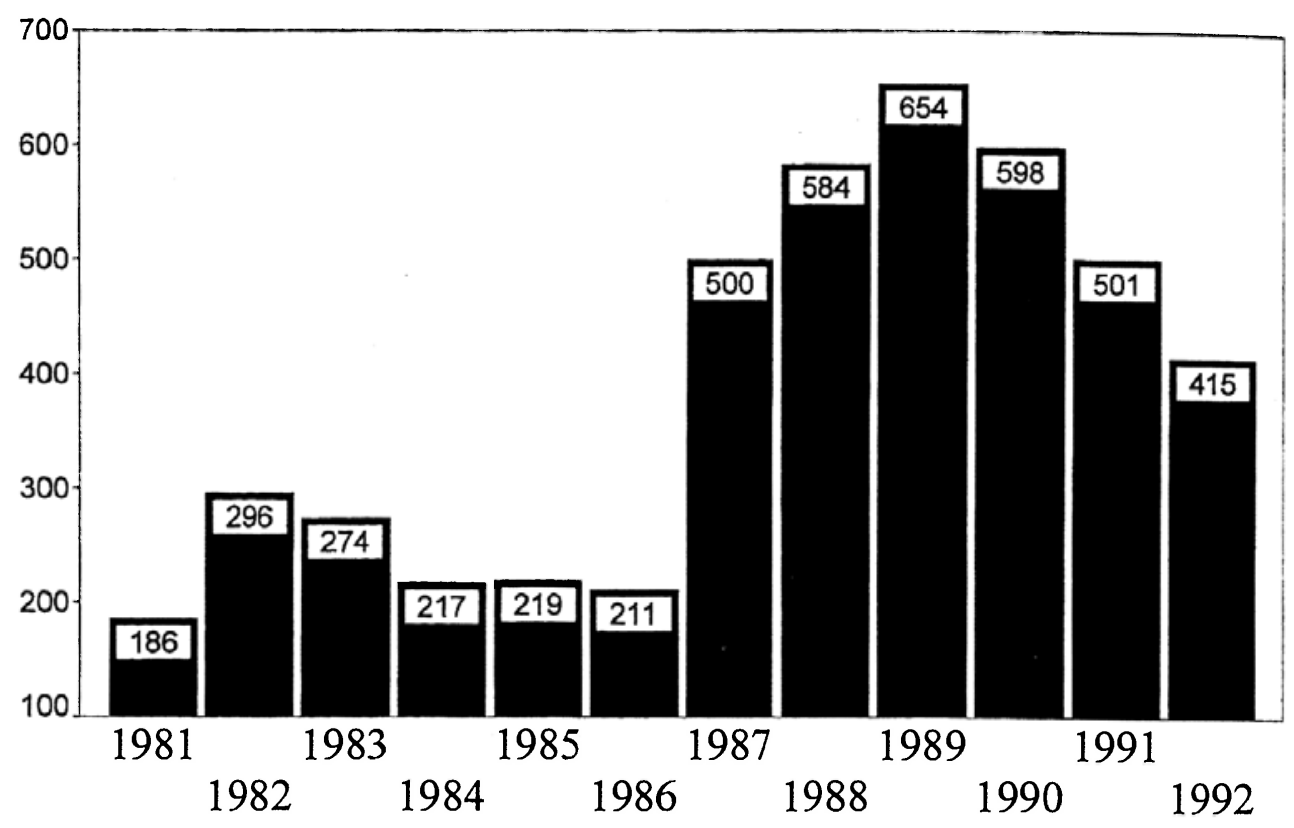

FIGURE 1.-Water-damaging accidents: Czech Republic, 1981-92. Source: Czech Water Inspection.

Czech environmental authorities treat water-damaging accidents as potential violations of statutes banning the improper handling of substances harmful to water. ${ }^{23}$ Once a water-damaging accident is detected, water authorities legally have two potential enforcement responses-remediation requirements and monetary fines-as part of their ex post liability policy. ${ }^{24,25}$ The theoretical model briefly sketched in the next section captures this type of pollution event.

\section{Theoretical Framework on Legal ENForcement}

For my purposes here, I choose to structure the enforcement of Czech water protection laws with respect to water-damaging accidents as a principal-agent model with moral hazard, where a single Czech water authoritythe principal-has regulatory control over a single polluter-the agent. In

${ }^{23}$ Water Act of 1973, Law No. 138 \& 23-24.

${ }^{24}$ Id, § 27; State Water Administration Act of 1974, Law No. $130 \S 24 \mathrm{c}$ (most recently amended by Czech National Council Act of 1992, Law No. 23).

${ }^{25}$ Analysis of all possible government means to control pollution is beyond the scope of this article. In particular, this analysis does not examine the formulation of ex ante policies concerning potential water-damaging accidents (in other words, ex ante regulations), enforcement of these ex ante policies (for example, facility inspections), or enforcement responses to detected violations (for example, forced plant closures). 
the principal-agent model, the polluter engages in a risky activity which randomly causes pollution. The polluter can provide costly effort that reduces the likelihood or severity of pollution and selects the level of effort that maximizes its expected indirect utility. Since enforcement is costly, the polluter is not always detected even though it has caused an accident. When the polluter is detected, the Czech water authority can impose a penalty which may include remediation and/or a monetary fine. When making these decisions, the principal selects an enforcement strategy that minimizes expected social costs. ${ }^{26}$

\section{Water-Damaging Accidents}

After framing the applicable theory, I next empirically analyze Czech authorities' use of remediation requirements and monetary fines as enforcement responses to water-damaging accidents-possible violations of statutes banning the improper handling of harmful substances. In particular, the analysis identifies whether water authorities applied a strict liability rule, which assigns penalties whenever damages are caused regardless of agents' effort, or a negligence rule, which assigns penalties only when effort is found to be negligent.

\section{A. Enforcement Responses to Water-Damaging Accidents}

No general procedure for imposing remediation requirements exists. However, in certain situations, the rule for imposing remediation requirements is dictated by test results of potentially contaminated soil and/or groundwater ${ }^{27}$ which indicates a strict liability rule since any preventive actions taken by the polluter are ignored ${ }^{28}$ However, according to the Water Act of 1973, remediation is only imposed when an obligation has been breached, suggesting a negligence rule. ${ }^{29}$.

The State Water Administration Act of 1974 guides monetary fines im-

${ }^{26}$ See note 40 below for details. This theoretical framework pertains only to optimal penalties and does not pertain to penalties chosen within a political context. Rather, this analysis assumes a political link between optimal and actual penalties in order to utilize the theory for guiding the subsequent empirical analysis.

${ }^{27}$ Environment Indices and Standards for the Decontamination of Soil and Groundwater, Procedures for the Assessment of the Obligations of Enterprises with Regard to Environmental Protection, Law No. 92/1991, Annex 2 § 3.

${ }^{28}$ In support of this view, Ministry of the Environment officials state that a property owner "must pay for remediation of its contaminated soil and groundwater even in cases when no regulation is found to be breached." Ladislav Bíža, private conversation (May 1993); Marketa Harbichová, private conversation (May 1993).

${ }_{29}$ Water Act of 1973 (cited in note 23), § 27. 
TABLE 1

Enforcement Responses to Water-Damaging Accidents, 1988-92

\begin{tabular}{|c|c|c|c|c|c|c|c|}
\hline \multirow[b]{2}{*}{ YEAR } & \multirow[b]{2}{*}{ ACCIDENTS } & \multicolumn{3}{|c|}{ MONETARY Fines } & \multicolumn{3}{|c|}{ REMEDIATION CosTS } \\
\hline & & $N$ & $\begin{array}{l}\text { Total Value } \\
\text { (1992 Kcs) }\end{array}$ & $\begin{array}{c}\text { Average } \\
\text { Value } \\
\text { (1992 Kčs) }\end{array}$ & $N$ & $\begin{array}{l}\text { Total Value } \\
\text { (1992 Kčs) }\end{array}$ & $\begin{array}{c}\text { Average } \\
\text { Value } \\
\text { (1992 Kčs) }\end{array}$ \\
\hline 1988 & 58 & 300 & $41,659,881$ & 138 & 44 & $9,276,627$ & 210,832 \\
\hline 1989 & & & & & 361 & 26 & 72,701 \\
\hline 1990 & 598 & 268 & $22,325,103$ & 83,3 & 170 & $12,077,124$ & 71,042 \\
\hline 1991 & 501 & 209 & $12,888,024$ & 61,665 & 43 & $9,449,791$ & 219,763 \\
\hline 1992 & 415 & 149 & $10,119,702$ & 67,917 & 41 & $19,661,021$ & 479,537 \\
\hline
\end{tabular}

Source.-Czech Inspection, Water Management Division, unpublished material.

NoTE.-Czech korunas (Kčs) deflated by the consumer price index for the Czech Republic (Source: Czech Statistical Office, Czech Statistical Yearbook, 1993).

posed on the organization responsible for an accident according to the following factors: ${ }^{30}$

1) the quantity and nature of the harmful substance,

2) the level of damages caused,

3 ) the effect on water quality and the sensitivity of the area,

4) the degree of protection granted to the affected water,

5) the entity's effort to remove harmful substances (in other words, remediation), and

6) circumstances.

A negligence rule appears to guide monetary fines since factor 6 permits water authorities to consider mitigating circumstances and the Water Act of 1973 stipulates monetary fines to be imposed only when a regulation has been breached. ${ }^{31}$

By law and frequently in practice, water authorities can and do impose remediation and monetary fines simultaneously. ${ }^{32}$ Table 1 presents a recent history of enforcement responses to water-damaging accidents. As shown, the annual number of accidents which have prompted a monetary fine has greatly decreased since 1988, even after taking into account the drop in accidents. More important, the average monetary fine imposed has dropped significantly. In the case of required remediation, the average remediation cost imposed has greatly increased since 1989 , even though the number of

${ }^{30}$ State Water Administration Act of 1974 (cited in note 24), § 24.

31 Water Act of 1973 (cited in note 23), § 47.

${ }^{32}$ Id, $\S \S 27,47$. 
remediation requirements in 1991 and 1992 is only a fraction of what was demanded in 1989 and 1990.

\section{B. The Database on Water-Damaging Accidents}

Since 1988, Czech Water Inspection has maintained a database on individual water-damaging accidents. An extract for the years 1988-92 includes the following penalties: (1) required remediation costs (adjusted to 1992 levels), and (2) a monetary fine (adjusted to 1992 levels). In addition, the database contains variables relevant to the Czech water authorities' decisions to impose penalties. Of these variables, this study utilizes the following:

1) type of water affected:

a) surface

b) ground

2) primary cause of the accident:
a) human error
b) technical (for example, improper maintenance of equipment)
c) other
d) transport
e) unknown/natural

3) secondary cause of the accident: ${ }^{33}$

a) human error

b) not human error

4) economic group of the responsible party:

a) agriculture

b) heavy industry

c) other industry

d) citizens

e) military/foreign

5) location of the accident by Czech Water Inspection region:
a) Brno
b) České Budèjovice
c) Havlíčkův Brod
d) Hradec Králové
e) Karlovy Vary
f) Liberec
g) Přerov/Olomouc ${ }^{34}$

${ }^{33}$ In some cases, two factors contribute to the cause of the accident.

${ }^{34}$ This region was renamed in 1989. 

h) Ostrava
i) Plzeň
j) Ústí nad Labem
k) Prague

6) year of the accident

7) measured damages caused by the accident (adjusted to 1992 levels)

8) type of contaminant involved:

a) oil contaminant

b) chemical contaminant

c) other contaminant

9) fish killed by the accident:

a) yes

b) no

The year and location of the accident can be linked to the surface water quality (here represented by biological oxygen demand) of the Czech Water Inspection region affected by the accident. ${ }^{35}$ The year of the accident places each observation in a political regime. For the purposes of empirical analysis, the years 1988-89 are regarded as a communist political regime, and the years 1990-92 are regarded as a democratic political regime because the old communist regime collapsed in November 1989. (Of course, this division disregards any transitional period when neither regime was dominant. Section II $A$ depicts a fairly quick transition, so this omission should have little effect on the results.) The database contains a total of 2,710 accidents; the responsible party was identified in 2,298 of these cases. Since penalties cannot be imposed on unidentified polluters, these observations are dropped from the analysis. ${ }^{36}$

Table 2 presents a statistical summary of all the included variables. First, note that damages were measured in only 421 of the 2,298 accidents. Second, note that the average damage measurement was about Kčs 40,000 (Kčs $=$ korunas), or less than $\$ 1,600$. According to an official at Czech Water

35 Although many parameters may represent water quality, the most prominent parameter is biological oxygen demand because it is reported in Czech Water Inspection's yearbooks.

${ }^{36}$ Complete documentation of the compiled data is available on request. The database lacks information on risk attitudes and enterprise insolvency constraints (in other words, imposed penalties exceed an enterprises's assets), which Shavell and Cohen show may critically determine the authorities' choice of an ex post liability rule. Shavell (cited in note 4); Cohen (cited in note 4). When the population of polluters is heterogeneous with respect to risk attitudes and insolvency constraints yet water authorities can discern these characteristics, the authorities may opt to match the chosen liability rule to each polluter. Lacking information on these characteristics for individual polluters, this analysis would fail to distinguish this matching of liability rules. In essence, this analysis would then only capture the dominant liability rule. I thank an anonymous referee for prompting this insight. 
TABLE 2

Statistical Summary of Accident Variables

A. Discrete Variables

\begin{tabular}{|c|c|c|}
\hline Variable and Value & $N$ & $\%$ \\
\hline \multicolumn{3}{|l|}{ Water: } \\
\hline Surface & 1,533 & 66.7 \\
\hline Ground & 765 & 33.3 \\
\hline \multicolumn{3}{|l|}{ Cause-primary: } \\
\hline Human error & 1,022 & 44.6 \\
\hline Technical & 505 & 22.0 \\
\hline Other & 111 & 4.8 \\
\hline Transport & 390 & 17.0 \\
\hline Unknown & 234 & 10.2 \\
\hline Natural & 36 & 1.6 \\
\hline \multicolumn{3}{|l|}{ Cause-secondary: } \\
\hline Human error & 556 & 24.3 \\
\hline Not human error & 1,742 & 75.8 \\
\hline \multicolumn{3}{|l|}{ Economic activity: } \\
\hline Agriculture & 651 & 28.3 \\
\hline Heavy industry & 652 & 28.4 \\
\hline Other industry & 713 & 31.0 \\
\hline Citizen & 45 & 2.0 \\
\hline Military/foreign & 237 & 10.3 \\
\hline \multicolumn{3}{|l|}{ Political regime: } \\
\hline Communist: $1988-89$ & 1,035 & 45.0 \\
\hline Democratic: $1990-92$ & 1,263 & 55.0 \\
\hline \multicolumn{3}{|l|}{ Contaminant: } \\
\hline Oil & 1,277 & 55.6 \\
\hline Chemical & 413 & 18.0 \\
\hline Other & 602 & 26.3 \\
\hline \multicolumn{3}{|l|}{ Damage measurement: } \\
\hline Measured & 421 & 18.3 \\
\hline Unmeasured & 1,877 & 81.7 \\
\hline \multicolumn{3}{|l|}{ Inspectorate region: } \\
\hline Brno & 226 & 9.8 \\
\hline Ceské Budèjovice & 228 & 9.9 \\
\hline Havličkův Brod & 40 & 1.7 \\
\hline Hradec Králové & 350 & 15.2 \\
\hline Karlovy Vary & 137 & 6.0 \\
\hline Liberec & 54 & 2.3 \\
\hline Přerov/Olomouc* & 239 & 10.4 \\
\hline Ostrava & 305 & 13.3 \\
\hline Plzeň & 157 & 6.8 \\
\hline Ústí nad Labem & 298 & 13.0 \\
\hline Prague & 264 & 11.5 \\
\hline \multicolumn{3}{|l|}{ Fish kill: } \\
\hline Yes & 423 & 18.4 \\
\hline No & 1,875 & 81.6 \\
\hline
\end{tabular}


TABLE 2 (Continued)

B. Continuous Variables

\begin{tabular}{|c|c|c|c|c|c|}
\hline Variable & Mean & $N \dagger$ & $\begin{array}{c}\text { Adjusted } \\
\text { Mean } \ddagger \\
(1992 \text { Kčs) }\end{array}$ & $\begin{array}{c}\text { Adjusted } \\
\text { Mean } \$ \\
\text { (1992 U.S. } \\
\text { Dollars) }\end{array}$ & SD \\
\hline Damages (1992 Kčs) & 8,064 & 421 & 44,015 & 1,566 & 114,742 \\
\hline $\begin{array}{l}\text { Surface water quality } \\
\text { (milligrams/liter) }\end{array}$ & 3.99 & 2,298 & $\cdots$ & & .951 \\
\hline Monetary fine (1992 Kčs) & 51,737 & 1,264 & 90,060 & 3,205 & 147,300 \\
\hline Remediation cost (1992 Kčs) & 32,560 & 609 & 122,862 & 4,372 & 296,581 \\
\hline
\end{tabular}

* Region renamed in 1989.

$\dagger$ Number of observations with positive values.

$\ddagger$ Includes only positive values.

$\S$ Includes only positive values. Czech $=$ U.S. exchange rate in 1992: 1 U.S. dollar $=28.1$ korunas. (Source: Business Central Europe. Country Indicators 73, (May 1993).)

Inspection, measurements generally include only certain components of environmental damages caused by accidents: losses from dead commercial fish and destroyed agricultural crops. ${ }^{37}$ Third, monetary fines actually imposed average about Kčs 90,000 , or $\$ 3,200$. Without information on business sales revenue or profits, it is difficult to understand the effect of these monetary fines. As a rough guide, in 1992, per capita gross domestic product (GDP) was $\$ 2,212$, and the average monthly wage was Kčs 4,689 , or $\$ 167 .{ }^{38}$ For international comparison, in 1991, the U.S. Environmental Protection Agency imposed administrative fines averaging \$23,937, while per capita GDP in the US was $\$ 22,699$ and the average monthly wage was $\$ 1,793 .{ }^{39}$ In absolute terms, the average Czech fine seems small compared to the average U.S. fine. However, after adjusting for differences in per capita income, the average Czech fine seems substantial compared to the average U.S. fine: the ratio of fine to per capita income is 1.45 for the Czech Republic yet only 1.05 for the United States. The same conclusion results when relating average fines to average monthly wages: the ratio of fine to wage is 19.21 for the Czech Republic yet only 13.35 for the United States. Fourth, remediation costs required by Czech water authorities averaged

37 Daniel Půlpán, private conversations (January-June 1993).

${ }^{38}$ Business Central Europe, Country Indicators 73 (May 1993); Czech Statistical Office, Survey of Indicators of Economics and Social Development, Czech Statistical Yearbook (1993).

${ }^{39}$ US Environmental Protection Agency, Enforcement Accomplishments Report: FY 1991 (Document No 300-R92-008, Office of Enforcement (LE-133), April 1992); US Department of Commerce-US Bureau of Labor Statistics, Monthly Labor Review-Employment and Earnings (March, June 1992). 
about Kčs 123,000 , or less than $\$ 4,400$. Since this cost is greater than the average Czech fine yet smaller than the average U.S. fine, similar conclusions can be drawn.

\section{Econometric Analysis of Water-Damaging Accidents}

Using the described data, I explore enforcement responses to waterdamaging accidents in the Czech Republic during the communist and democratic political periods by determining the driving factors behind the two penalty decisions. In particular, I explore whether Czech enforcement responses changed in noticeable ways between the two political systems.

\section{A. Structuring the Outcome Relationships and Estimation Techniques}

Each accident entails a decision on both required remediation costs and imposed monetary fines. Therefore, econometric analysis must estimate the joint determination of these enforcement responses, which warrants a simultaneous equations model. However, the principal-agent model implies that determination of the dependent variables is recursive; in other words, the principal chooses the level of remediation first, independent of the monetary fine, and the monetary fine second, dependent on the costs of the chosen remediation level. ${ }^{40}$ In a fully recursive model, where all error terms are uncorrelated, the regression system can be estimated consistently and efficiently using equation-by-equation analysis: $:^{41}$ (1) remediation costs as a function of the explanatory variables, and (2) monetary fines as a function of the same explanatory variables, plus remediation costs. ${ }^{42}$

40 To understand the recursive nature of these decisions, note that the principal's objective consists of two independent concerns: (1) pollution damages and remediation costs associated with each particular accident and (2) deterrence. For each level of pollution caused by a given accident, the principal chooses the optimal level of remediation, which minimizes the sum of remediation costs and environmental damages caused by any remaining pollution following remediation. Thus, remediation is chosen solely for environmental reasons. Even though remediation costs constitute part of the total penalty imposed on the polluter, deterrence is based solely on the total penalty as a whole, not its individual components. In order to create the proper level of deterrence, the principal chooses an optimal schedule of total penalties for all levels of pollution, which induces the polluter to provide effort that minimizes expected social costs. The optimal monetary fine is simply the difference between the optimal total penalty and the cost of optimal remediation. In essence, the optimal level of remediation is selected first, and the optimal monetary fine-the additional punch needed to provide the proper deterrence-is selected second.

${ }^{41}$ William Greene, Econometric Analysis (1993).

42 As one means of testing this recursive structure, I combine the two penalties into a single dependent variable and compare the estimation results with those for the two penalties separately. Coefficient estimates for the composite penalty significantly differ from the estimates for both individual penalties in both political periods. In the case of remediation costs, Wald test statistics for the communist and democratic periods are 200.1 and 166.8, respectively, both significant at the 1 percent level. For monetary fines, Wald test statistics for the communist and democratic periods are 249.7 and 204.9, respectively, both significant at the 
In turn, I estimate two separate econometric models based on the time period used to establish the relationships between the dependent and explanatory variables. Model 1 uses data for the years 1988-89-the communist political regime. Model 2 uses data for the years 1990-92 - the democratic political regime. I do not pool the data since I find a structural break in the regression system between the two political regimes. Estimates of the coefficients common to the two models, as a group, differ significantly between the political regimes. Wald test statistics for remediation costs and monetary fines are 117.1 and 61.2, respectively, both significant at the 1 percent level.

In the case of remediation costs, I choose a log-linear specification based on results from a test for linearity versus log linearity. ${ }^{43}$ For both political regimes, I can reject the linear specification but cannot reject the log-linear specification. ${ }^{44}$ As for monetary fines, I choose a linear specification based on results from the identical test noted above. For the communist regime, I cannot reject the linear specification but can reject the log-linear specification. However, for the democratic regime, I generate the opposite results; I can reject the linear specification but cannot reject the log-linear specification. ${ }^{45}$ In order to compare the empirical results between the two political periods, I must use only one specification. Theory suggests that the linear specification is more appropriate.

Censoring affects both dependent variables. Required remediation costs are bottom-censored at zero- 1,689 of the 2,298 accidents prompted no remediation. According to the State Water Administration Act of 1974, the monetary fine is bottom-censored at Kčs 10,000 and top-censored at Kčs $1,000,000$ (both in nominal terms). ${ }^{46}$ An examination of the data reveals that

\footnotetext{
1 percent level. (I thank an anonymous referee for this suggested comparison.) As a second means of testing the recursive structure, I show that the coefficient estimates for the two individual penalties differ significantly in both political periods. Wald test statistics for the communist and democratic periods are 381.0 and 274.2, respectively, both significant at the 1 percent level. All of these results support the recursive structure.

${ }_{43}$ R. Davidson and J. MacKinnon, Several Tests for Model Specification in the Presence of Alternative Hypotheses, 49 Econometrica 781 (1981).

44 t-test statistics for the linear and log-linear specifications in model 1 (communist regime) are -7.01 and 1.55 , respectively, and are significant at 1 percent and 12 percent levels, respectively. $t$-test statistics for the linear and log-linear specifications in model 2 (democratic regime) are -11.02 and 1.22 , respectively, and are significant at 1 percent and 22 percent levels, respectively.

$45 t$-test statistics for the linear and log-linear specifications in model 1 (communist regime) are -1.23 and 2.12 , respectively, and are significant at 22 percent and 5 percent levels, respectively. $t$-test statistics for the linear and log-linear specifications in model 2 (democratic regime) are -5.15 and 1.04 , respectively, and are significant at 1 percent and 30 percent levels, respectively.

${ }^{46}$ State Water Administration Act of 1974 (cited in note 24), § 24.
} 
top-censoring appears not to be important: the maximum monetary fine is imposed in only five cases. As further evidence, inclusion of a top limit in the estimation fails to alter significantly the coefficient estimates ${ }^{47}$ Consequently, the top-censoring problem is ignored. Also on examination, the bottom-censoring of monetary fines actually occurs at Kčs 0 -not Kčs $10,000 .^{48}$ Zero values indicate censoring in both dependent variables since Czech water authorities may wish to impose negative penalties in order to induce the optimal effort from polluters. As one way of handling this complication, I make the Tobit assumptions and estimate the regression system with maximum likelihood techniques. ${ }^{49}$ Estimation results of remediation costs and monetary fines are given in Tables 3 and 4, respectively.

\section{B. Estimation Results and Interpretations}

The driving factors behind penalty decisions divide into five main categories: information on preventive effort (in other words, causes of accidents), measured damages, environmental factors, regional factors, and political influence.

How information on preventive effort and measured damages drives penalty decisions can be discerned by identifying the operative liability rule. First, I establish a connection between accident causes and negligence. In the case of primary causes, judged against some standard of preventive effort, human errors and technical errors indicate negligence, while unknown or natural causes indicate lack of negligence; the translation of "other" and transport causes into negligence is left ambiguous. Given this logic, I create a measure of negligence by establishing unknown/natural causes as the benchmark against which I judge the relative effects of the remaining cause categories. Similarly, in the case of secondary causes, I create a measure of negligence by establishing "not human error" as the benchmark against which I judge the relative effect of secondary human error. Given this mapping between causes and negligence, the relative effects of cause categories should be zero under a strict liability rule and positive under a negligence rule. See Table 5 for how coefficient signs of cause variables relate to liability rules.

In general, greater damages should lead to higher penalties. Under a strict

${ }^{47}$ Since the legal limit of Kčs 1 million applies to nominal values, I estimate the monetary fine equation for each individual year. Wald test statistics for the years 1988 through 1992 are $0.004,0.000,0.193,0.065$, and 0.000 , respectively, and are significant only at levels greater than 10 percent.

${ }^{48}$ Of course, I cannot rule out the possibility that a certain percentage of the accidents are bottom-censored at Kčs 10,000 and the remaining accidents are not.

${ }^{49}$ G. S. Maddala, Limited-Dependent and Qualitative Variables in Econometrics (1983). 
TABLE 3

Tobit Estimation of Remediation Costs (Logarithm Values)

\begin{tabular}{|c|c|c|c|}
\hline Variable & $\begin{array}{c}\text { Communist } \\
\text { Regime }\end{array}$ & $\begin{array}{l}\text { Democratic } \\
\text { Regime }\end{array}$ & Difference $^{a}$ \\
\hline Primary human cause ${ }^{1}$ & $\begin{array}{l}1.932 * * \\
(.843)\end{array}$ & $\begin{array}{c}1.742 \\
(1.401)\end{array}$ & \\
\hline Other cause $^{1}$ & $\begin{array}{c}2.042 \\
(1.327)\end{array}$ & $\begin{array}{c}.868 \\
(2.075)\end{array}$ & \\
\hline Transport cause $^{1}$ & $\begin{array}{l}1.651^{*} \\
(.994)\end{array}$ & $\begin{array}{c}.656 \\
(1.544)\end{array}$ & \\
\hline Technical cause $^{1}$ & $\begin{array}{l}2.630^{* * *} \\
(.872)\end{array}$ & $\begin{array}{l}1.429 \\
(1.450)\end{array}$ & \\
\hline Secondary human cause ${ }^{2}$ & $\begin{array}{l}.770 \\
(.629)\end{array}$ & $\begin{aligned}-1.046 \\
(.937)\end{aligned}$ & .10 \\
\hline $\ln$ (measured damages) & $\begin{array}{l}1.199 * * * \\
(.066)\end{array}$ & $\begin{array}{l}2.068 * * * \\
(.110)\end{array}$ & .01 \\
\hline Agriculture $^{3}$ & $\begin{array}{l}-3.551^{* * * *} \\
(.673)\end{array}$ & $\begin{array}{r}-.289 \\
(.990)\end{array}$ & .01 \\
\hline Other industry ${ }^{3}$ & $\begin{array}{l}-2.848^{* * * *} \\
(.625)\end{array}$ & $\begin{array}{l}-2.282^{* * *} \\
(.944)\end{array}$ & \\
\hline Citizens $^{3}$ & $\begin{array}{l}-9.832 * * * \\
(4.004)\end{array}$ & $\begin{array}{l}-.658 \\
(2.278)\end{array}$ & .05 \\
\hline Military/foreign entities ${ }^{3}$ & $\begin{array}{c}-5.046^{* * * *} \\
(1.031)\end{array}$ & $\begin{array}{c}-3.141^{* *} \\
(1.385)\end{array}$ & \\
\hline Groundwater ${ }^{4}$ & $\begin{array}{r}-.070 \\
(.544)\end{array}$ & $\begin{array}{l}1.325^{*} \\
(.784)\end{array}$ & \\
\hline In(surface water quality) & $\begin{array}{c}7.214 \\
(4.631)\end{array}$ & $\begin{array}{c}4.890 \\
(4.593)\end{array}$ & \\
\hline Oil contaminant ${ }^{5}$ & $\begin{array}{l}-.849 \\
(.634)\end{array}$ & $\begin{array}{l}2.973 * * * \\
(1.049)\end{array}$ & .01 \\
\hline Chemical contaminant ${ }^{5}$ & $\begin{array}{l}-2.062 * * * \\
(.793)\end{array}$ & $\begin{array}{l}1.295 \\
(1.231)\end{array}$ & .01 \\
\hline $\mathrm{Brno}^{6}$ & $\begin{array}{c}.717 \\
(1.096)\end{array}$ & $\begin{array}{l}4.592 * * * \\
(1.610)\end{array}$ & .05 \\
\hline Ceské Budèjovice ${ }^{6}$ & $\begin{array}{l}7.389 * * * \\
(1.935)\end{array}$ & $\begin{array}{l}6.092 * * \\
(2.989)\end{array}$ & \\
\hline Havlíčkův Brod ${ }^{6, b}$ & & $\begin{array}{l}-24.683 \\
(217.4)\end{array}$ & \\
\hline Hradec Králové ${ }^{6}$ & $\begin{array}{l}4.506^{* *} \\
(1.965)\end{array}$ & $\begin{array}{l}4.340 * * \\
(2.003)\end{array}$ & \\
\hline Karlovy Vary ${ }^{6}$ & $\begin{array}{c}2.894 \\
(1.886)\end{array}$ & $\begin{array}{c}2.784 \\
(2.611)\end{array}$ & \\
\hline Liberec $^{6, b}$ & & $\begin{array}{l}7.652 * * \\
(3.718)\end{array}$ & \\
\hline Prerov/Olomouc ${ }^{6}$ & $\begin{array}{l}3.019 * * \\
(1.352)\end{array}$ & $\begin{array}{c}2.809^{*} \\
(1.647)\end{array}$ & \\
\hline Ostrava $^{6}$ & $\begin{array}{l}5.177^{* *} \\
(2.643)\end{array}$ & $\begin{array}{l}5.635^{* * *} \\
(2.211)\end{array}$ & \\
\hline Plzeň $^{6}$ & $\begin{array}{l}10.006^{* * *} \\
(2.366)\end{array}$ & $\begin{array}{l}11.808^{* * *} \\
(3.124)\end{array}$ & \\
\hline Ústí nad Labem ${ }^{6}$ & $\begin{array}{l}1.961^{* *} \\
(.971)\end{array}$ & $\begin{array}{l}.102 \\
(1.882)\end{array}$ & \\
\hline
\end{tabular}


TABLE 3 (Continued)

\begin{tabular}{lccc}
\hline \hline Variable & $\begin{array}{c}\text { Communist } \\
\text { Regime }\end{array}$ & $\begin{array}{c}\text { Democratic } \\
\text { Regime }\end{array}$ & Difference $^{\mathrm{a}}$ \\
\hline Fish kill & .587 & -.694 & \\
& $(.628)$ & $(1.028)$ & \\
No. of observations & 1,035 & 1,263 & \\
Normal SD & 5.637 & 7.624 & \\
Log-likelihood & $-1,397$ & $-1,008$ & \\
\hline
\end{tabular}

Nore.-Standard errors are in parentheses. Regression also includes a constant and indicator variables for individual years, coefficients for which are not shown here. Omitted indicator categories are designated by superscript numbers: $1=$ unknown/natural causes; $2=$ not human error; $3=$ heavy industry; $4=$ surface water; $5=$ other contaminant; $6=$ Prague inspectorate region; and $7=$ no fish kill.

a This is the significance level of statistical difference between two estimates.

h There are no observations in the inspectorate region under the communist regime.

* Statistically significant at the .10 level.

** Statistically significant at the .05 level.

*** Statistically significant at the .01 level.

liability rule, penalties are imposed whenever damages are caused; thus, the effect of damages on penalties is large. Under a negligence rule, penalties are imposed only when effort is deemed negligent; thus, the effect of damages is smaller than under a strict liability rule. In the case of remediation costs, the coefficient on damages does not identify which rule is operative because the optimal level of remediation depends not only on damages but also on the cost structure of remediation. ${ }^{50}$ In the case of monetary fines, an identifiable benchmark value for the coefficient on measured damages delineates which rule is operative. Since the probability of detection is definitely less than one (recall that Czech Water Inspection identified 2,710 accidents but detected the responsible party in only 2,298 of these cases) and inflation of detected damages is needed to provide deterrence from undetected damages, under a strict liability rule the coefficient on damages is greater than one. ${ }^{51}$ The coefficient is less than one only under a negligence rule, given that negligence varies within each cause category (for example, human error can be both minor and egregious). ${ }^{52}$ However, coefficients greater than one can occur under both rules. Under a negligence rule, a sufficiently low probability of detection, requiring inflation of the monetary fine in order to provide necessary deterrence from undetected damages, can offset the weaker connection between damages and monetary fines and

${ }^{50}$ For details on the optimal level of remediation, see note 40 above; and Cohen (cited in note 4).

${ }^{51}$ For details on optimal monetary fines, see Cohen (cited in note 4).

${ }_{52}$ The coefficient can be less than one, even under a strict liability rule, if polluters bear costs in addition to the two penalties, such as reputational losses. I thank a referee for this point. 
TABLE 4

Tobit Estimation of Monetary Fines

\begin{tabular}{|c|c|c|c|}
\hline Variable & $\begin{array}{l}\text { Communist } \\
\text { Regime }\end{array}$ & $\begin{array}{l}\text { Democratic } \\
\text { Regime }\end{array}$ & Difference $^{a}$ \\
\hline Primary human cause $^{1}$ & $\begin{array}{c}-21,981 \\
(26,860)\end{array}$ & $\begin{array}{r}-22,182 \\
(18,290)\end{array}$ & \\
\hline Other cause ${ }^{1}$ & $\begin{array}{r}-86,130^{*} \\
(45,880)\end{array}$ & $\begin{array}{c}-75,153^{* * *} \\
(30,630)\end{array}$ & \\
\hline Transport cause ${ }^{1}$ & $\begin{array}{c}-59,040^{*} \\
(34,010)\end{array}$ & $\begin{array}{c}-32,009 \\
(20,640)\end{array}$ & \\
\hline Technical cause ${ }^{1}$ & $\begin{array}{l}-3,804 \\
(28,800)\end{array}$ & $\begin{array}{c}10,447 \\
(18,780)\end{array}$ & \\
\hline Secondary human cause ${ }^{2}$ & $\begin{array}{c}6,538 \\
(22,700)\end{array}$ & $\begin{array}{l}41,556 * * * \\
(12,660)\end{array}$ & \\
\hline Measured damages & $\begin{array}{l}.235^{* * * *} \\
(.067)\end{array}$ & $\begin{array}{c}.098 \\
(.102)\end{array}$ & \\
\hline Remediation costs & $\begin{array}{r}-.055^{*} \\
(.031)\end{array}$ & $\begin{array}{l}.050 * * \\
(.023)\end{array}$ & .01 \\
\hline Agriculture $^{3}$ & $\begin{array}{c}-23,061 \\
(22,980)\end{array}$ & $\begin{array}{c}-12,015 \\
(13,700)\end{array}$ & \\
\hline Other industry ${ }^{3}$ & $\begin{array}{c}-79,346^{* * * *} \\
(22,340)\end{array}$ & $\begin{array}{c}-19,896 \\
(12,610)\end{array}$ & .05 \\
\hline Citizens $^{3}$ & $\begin{array}{c}-1,171,900 \\
(9,160,000)\end{array}$ & $\begin{array}{c}-719,460 \\
(5,010,000)\end{array}$ & \\
\hline Military/foreign entities ${ }^{3}$ & $\begin{array}{c}-279,650^{* * *} \\
(38,540)\end{array}$ & $\begin{array}{c}-168,890^{* * * *} \\
(23,860)\end{array}$ & .01 \\
\hline Groundwater $^{4}$ & $\begin{array}{c}24,113 \\
(19,480)\end{array}$ & $\begin{array}{c}8,602 \\
(10,990)\end{array}$ & \\
\hline Surface water quality & $\begin{array}{c}-39,652 \\
(38,000)\end{array}$ & $\begin{array}{l}23,199^{*} \\
(13,890)\end{array}$ & \\
\hline Oil contaminant ${ }^{5}$ & $\begin{array}{l}55,797 * * * \\
(22,390)\end{array}$ & $\begin{array}{l}-4,513 \\
(13,460)\end{array}$ & .05 \\
\hline Chemical contaminant $^{5}$ & $\begin{array}{c}48,760^{*} \\
(27,450)\end{array}$ & $\begin{array}{l}-6,197 \\
(16,010)\end{array}$ & .10 \\
\hline $\mathrm{Brno}^{6}$ & $\begin{array}{l}158,970 * * * \\
(33,640)\end{array}$ & $\begin{array}{l}-8,888 \\
(23,510)\end{array}$ & .01 \\
\hline České Budèjovice ${ }^{6}$ & $\begin{array}{c}10,101 \\
(68,730)\end{array}$ & $\begin{array}{l}131,560^{* * *} \\
(34,080)\end{array}$ & \\
\hline Havlíčkův Brod ${ }^{6 . b}$ & & $\begin{array}{l}93,877 * * * \\
(31,180)\end{array}$ & \\
\hline Hradec Králové ${ }^{6}$ & $\begin{array}{c}38,973 \\
(61,590)\end{array}$ & $\begin{array}{l}77,316 * * * \\
(25,150)\end{array}$ & \\
\hline Karlovy Vary ${ }^{6}$ & $\begin{array}{l}126,610^{*} \\
(69,730)\end{array}$ & $\begin{array}{l}119,370 * * * \\
(32,400)\end{array}$ & \\
\hline Liberec $^{6, b}$ & & $\begin{array}{c}57,447 \\
(41,640)\end{array}$ & \\
\hline Prerov/Olomouc ${ }^{6}$ & $\begin{array}{c}21,989 \\
(46,020)\end{array}$ & $\begin{array}{c}22,891 \\
(22,600)\end{array}$ & \\
\hline Ostrava $^{6}$ & $\begin{array}{c}-90,392 \\
(83,350)\end{array}$ & $\begin{array}{l}72,470 * * * \\
(27,710)\end{array}$ & .10 \\
\hline Plzeñ $^{6}$ & $\begin{array}{c}40,860 \\
(77,370)\end{array}$ & $\begin{array}{l}132,210^{* * *} \\
(36,650)\end{array}$ & \\
\hline Üstí nad Labem ${ }^{6}$ & $\begin{array}{l}129,970 * * * \\
(33,590)\end{array}$ & $\begin{array}{l}77,251^{* * *} \\
(24,050)\end{array}$ & \\
\hline
\end{tabular}


TABLE 4 (Continued)

\begin{tabular}{lccc}
\hline \hline Variable & $\begin{array}{c}\text { Communist } \\
\text { Regime }\end{array}$ & $\begin{array}{c}\text { Democratic } \\
\text { Regime }\end{array}$ & Difference $^{\text {a }}$ \\
\hline Fish kill & 17,489 & 550 & \\
& $(22,530)$ & $(14,320)$ & \\
No. of observations & 1,035 & 1,263 & \\
Normal SD & 239,840 & 149,670 & \\
Log-likelihood & $-9,045$ & $-8,664$ & \\
\hline
\end{tabular}

NoTE.-Standard errors are in parentheses. Regression also includes a constant and indicator variables for individual years, coefficients for which are not shown here. Omitted indicator categories are designated by superscript numbers: 1 = unknown/natural causes; 2 = not human error; 3 = heavy industry; $4=$ surface water; $5=$ other contaminant; $6=$ Prague inspectorate region; and $7=$ no fish kill.

${ }^{2}$ This is the significance level of statistical difference between two estimates.

${ }^{\mathrm{b}}$ There are no observations in the inspectorate region under the communist regime.

* Statistically significant at the .10 level.

** Statistically significant at the .05 level.

$* * *$ Statistically significant at the .01 level.

cause the coefficient to be greater than one. See Table 5 for details on how coefficient magnitudes for damages relate to liability rules.

First, I examine the liability rule for required remediation costs. As shown in Table 5, panel A, accidents caused primarily by human error, technical error, or transport events prompted greater remediation costs than accidents caused primarily by unknown or natural causes in the communist period. In the democratic period, however, accident causes do not influence remediation costs. With respect to measured damages, accidents causing greater damages prompted higher remediation costs in both political periods. Also, the effect of damages is significantly greater in the democratic period than in the communist period. These results indicate that a negligence rule appears to guide remediation requirements in the communist period, ${ }^{53}$ while a strict liability rule appears to guide remediation requirements in the democratic period. ${ }^{54}$ Apparently, the Water Act's stipulation dominates in the communist period, while the particular rule for remediating

${ }^{53}$ Under a negligence rule, the costs of performing the optimal level of remediation are not imposed on the polluter when its effort is deemed nonnegligent. Instead, the government (or society) bears these costs. In the case of water-damaging accidents, no available data show that Czech authorities, rather than the responsible polluter, ever bore the cost of remediation, regardless of the polluter's effort. However, when authorities failed to identify the responsible polluter (in 412 cases), authorities bore the cost of remediation in 50 cases, averaging $\mathrm{K} \check{c}$ s 37,735 , or $\$ 1,343$.

${ }^{54}$ As noted below, political influence appears less important in the democratic period than in the communist period. If true, without controlling for all political influence, this analysis may discern a stronger relationship between damages and remediation costs in the democratic period, regardless of any shift in the operative liability rule. I thank an anonymous referee for this point. 
TABLE 5

Operative Liability Rules: Coefficient Signs and Magnitudes

\begin{tabular}{|c|c|c|c|c|c|}
\hline \multirow[b]{3}{*}{ VARIABLE } & \multicolumn{2}{|c|}{$\begin{array}{c}\text { EXPECTED } \\
\text { COEFfICIENT } \\
\end{array}$} & \multirow{2}{*}{\multicolumn{3}{|c|}{ Estimated CoEfficient $^{\mathrm{a}}$}} \\
\hline & \multirow{2}{*}{$\begin{array}{c}\text { Strict } \\
\text { Liability }\end{array}$} & \multirow[b]{2}{*}{ Negligence } & & & \\
\hline & & & Communist & Democratic & Difference $^{b}$ \\
\hline \multicolumn{6}{|l|}{$\begin{array}{l}\text { A. Required remediation } \\
\text { costs (logarithm } \\
\text { values): }\end{array}$} \\
\hline Human cause & $=0$ & $>0$ & $>0 * *$ & $=0$ & \\
\hline Other cause & $=0$ & $>0$ & $=0$ & $=0$ & \\
\hline Transport cause & $=0$ & $>0$ & $>0 *$ & $=0$ & \\
\hline Technical cause & $=0$ & $>0$ & $>0 * * *$ & $=0$ & \\
\hline Secondary human cause & $=0$ & $>0$ & $=0$ & $=0$ & .10 \\
\hline $\ln$ (measured damages) & $\gg 0$ & $>0$ & $\begin{array}{c}>0 * * * \\
{[=1.199]}\end{array}$ & $\begin{array}{c}>0 * * * \\
{[=2.068]}\end{array}$ & .01 \\
\hline \multicolumn{6}{|l|}{ B. Monetary fines: } \\
\hline Human cause & $=0$ & $>0$ & $=0$ & $=0$ & \\
\hline Other cause & $=0$ & $>0$ & $<0 *$ & $<0 * * *$ & \\
\hline Transport cause & $=0$ & $>0$ & $<0 *$ & $=0$ & \\
\hline Technical cause & $=0$ & $>0$ & $=0$ & $=0$ & \\
\hline Secondary human cause & $=0$ & $>0$ & $=0$ & $>0 * * *$ & \\
\hline Measured damages & $>1$ & $>0$ & $\begin{array}{c}<1 * * * \\
{[=.235]}\end{array}$ & $\begin{array}{c}<1 * * * \\
{[=.098]}\end{array}$ & \\
\hline
\end{tabular}

NoTE. - The $t$-statistics for testing whether the coefficient on measured damages for monetary fines is less than one for the communist regime and the democratic regime are, respectively, 11.42 and 8.84 .

${ }^{a}$ Estimated coefficient signs indicated as equal to zero are significantly different from zero at a level higher than 0.10 .

${ }^{\mathrm{b}}$ Significance level of statistical difference between coefficient estimates using a Wald test.

* Statistically significant at the .10 level.

** Statistically significant at the .05 level.

*** Statistically significant at the .01 level.

contaminated soil and/or groundwater generalizes only for the democratic period.

Next, I examine the liability rule for assigning monetary fines. As shown in Table 5, panel B, in both political periods, accidents caused primarily by "other' factors prompted lower monetary fines than accidents caused primarily by unknown or natural factors, inconsistent with either liability rule. ${ }^{55}$ Similarly, in the communist period, accidents caused primarily by transport factors prompted lower monetary fines. In the democratic period,

${ }^{55}$ Uncertainty surrounding evidence necessary to prove negligence may affect the cause coefficients. In particular, it may be more difficult to prove negligence in cases involving "other" causes, relative to more prominent causes, such as human errors. For more information on uncertainty and a negligence rule, see Richard Craswell and John Calfee, Deterrence and Uncertain Legal Standards, 2 J L, Econ, \& Org 279 (1986). 
secondary human error increased monetary fines. Otherwise, accident causes do not seem to influence monetary fine decisions, giving little support to a negligence rule operating. Nevertheless, the coefficient on measured damages is significantly less than one in both political periods, unambiguously indicating a negligence rule. These conclusions are consistent with my expectations.

In addition to accident causes and damages, environmental, regional, and political factors drive penalty decisions. Environmental factors offer insight into broader policy objectives and may provide information on unmeasured damages, which may prove quite important, given the frequency of damage measurements and the inclusion of only certain damage components.

When considering remediation costs, estimates give quite interesting results, as shown in Table 3. First, in the democratic period, accidents damaging groundwater prompted higher penalties than accidents damaging surface water. This result is consistent with Czech authorities' concerns for groundwater expressed in a 1991 government decree granting special protection to groundwater sources and in Czech Water Inspection's yearbooks. ${ }^{56}$ This result is also consistent with the notion that groundwater is generally more costly to remediate. Second, in the democratic period, accidents involving oil contaminants prompted greater remediation costs than accidents involving "other" contaminants, which is consistent with the concern for oil contaminants expressed in Czech Water Inspection's yearbooks. In the communist period, chemical contaminants decreased remediation costs relative to "other" contaminants. In both cases, the effect of contaminant type possibly captures the cost side of remediation decisions.

The estimated effects of regional factors indicate that no inspectorate imposed less stringent remediation requirements than the Prague inspectorate during both political periods. Perhaps this result reflects greater political influence on the part of polluters located in the capital city region of Prague.

Political influence, as captured by the effects of different economic groups on penalty decisions, explains how certain groups of polluters receive relatively harsh or preferential treatment according to their political position or maneuvering. Surprisingly, heavy industry received the harshest remediation requirements of all economic groups in both political periods. Under communism, the former Czechoslovak government greatly promoted heavy industry. Central planning policies "promoted an economic structure biased toward heavy industries and the energy sector, which accounted for approximately $60 \%$ of total output throughout the 1980's." ${ }^{57}$ However, this

${ }^{56}$ Czech Government Decree No. 85/1991.

57 World Bank (cited in note 2). 
promotion did not translate into preferential treatment. ${ }^{58}$ Relative to heavy industry, military and foreign entities did receive preferential treatment in both periods. Most likely, these entities were beyond the regulatory control of water authorities, especially under communism, since water authorities probably lacked power vis-à-vis stronger state organizations, as suggested by the Czech Ministry of the Environment. ${ }^{59}$ This result is consistent with Catherine Albrecht's depiction of Czechoslovak environmental authorities' relative power. ${ }^{60}$

Although present in both periods, the importance of political influence is more pronounced in the communist period, consistent with the greater potential for and reliance on political maneuvering in that period. As a group, the effects of various economic groups are significantly greater in the communist period. ${ }^{61}$ As for changes in individual economic categories, both agriculture and citizens were treated significantly less favorably (relative to heavy industry) in the democratic period than in the communist period.

In the case of monetary fines, estimates also give intriguing results, as shown in Table 4 . Judging by the effects of surface water quality, authorities shifted from a neutral stance with respect to protection priorities in the communist period to a strategy emphasizing the correction of problem areas (in other words, low water quality) in the democratic period. Accidents involving either oil or chemical contaminants prompted higher monetary fines than accidents involving "other" contaminants in the communist period. Apparently, water authorities followed the State Water Administration Act of 1974 by incorporating the nature of the harmful substance into monetary fine decisions. In addition, the coefficients on the two indicator variables for the contaminant type are significantly greater in the communist period than in the democratic period. In this regard, monetary fine decisions were more sensitive to unmeasured damages in the communist period than in the democratic period.

As for regional factors, the effects of various inspectorate regions reveal that no inspectorate imposed lower monetary fines than Prague in both political periods, similar to remediation requirements. In addition, this prefer-

\footnotetext{
${ }^{58}$ One possible explanation for this result is that heavy industry is positively correlated with the severity of accidents not captured by the included explanatory variables.

${ }^{59}$ Czech Ministry of the Environment (cited in note 5).

${ }^{60}$ Catherine Albrecht, Environmental Policies and Politics in Contemporary Czechoslovakia, 20 Stud Comp Communism 291 (1987). Other analyses depict a similar relationship in the former Soviet Union. See Charles Ziegler, Environmental Policy in the USSR (1987); D. J. Peterson, Troubled Lands: The Legacy of Soviet Environmental Destruction (1993).

${ }^{61}$ The Wald test statistic is 11.28 and is significant at the 5 percent level.
} 
ential treatment offered to Prague polluters is more prominent in the democratic period. ${ }^{62}$

As with remediation requirements, political influence is evident under both regimes. In both periods, heavy industry received the highest monetary fines of all economic groups (contrary to expectations), ${ }^{63}$ while military and foreign entities received significantly favorable treatment (relative to heavy industry). In addition, "other" industry received favorable treatment under communism. Moreover, the importance of political influence is more pronounced under the communist regime, also similar to remediation requirements. As a group, the effects of economic groups are significantly greater in the communist period. ${ }^{64}$ This result, especially with regard to military and foreign entities, may not be surprising given the democratic government's efforts to restructure Czech society.

\section{SUMMARY}

This article examines the enforcement of water protection laws in the Czech Republic using data on penalties imposed in response to waterdamaging accidents during the years 1988-92. Empirical analysis explores the driving factors behind penalty decisions during the two political regimes-communism and democracy - separately and compares the results. In particular, it identifies the operative liability rules. Based on my reading of Czech water regulations and personal conversations with Czech environmental officials, a strict liability or a negligence rule may guide remediation requirements, while a negligence rule should guide monetary fines.

Estimation of enforcement responses gives the following results. The liability rule guiding remediation requirements shifts from a negligence rule in the communist period to a strict liability rule in the democratic period, while a negligence rule guides monetary fines in both political periods. Most interesting, political influence drives both penalty decisions, especially under communism; most prominent is the preferential treatment given to military and foreign entities and the diminished preference shown during the democratic period. In addition, the effects of surface water quality and

${ }^{62}$ As additional evidence, collectively the effects of individual inspectorate regions are significantly different between the two political periods. The Wald test statistic is 31.67 and is significant at the 0.5 percent level.

${ }^{63}$ One possible explanation is a positive correlation between heavy industry and the severity of accidents not captured by this analysis. As a second possible explanation, any greater recidivism in heavy industry would have prompted higher monetary fines according to the State Water Administration Act (cited in note 24), § 24.

${ }^{64}$ The Wald test statistic is 9.48 and is significant at the 5 percent level. 
type of affected water indicate broader water protection policies. Similarly, penalties varied significantly across individual regions reflecting efforts to accommodate local conditions.

The identified liability rules for remediation requirements reflect the ambiguity of my prior expectations, while the identified liability rules for monetary fines match nicely with my prior expectations. The greater importance of political influence in the communist period is consistent with the potential for and reliance on political maneuvering in that period. The preferential treatment granted military and foreign entities under communism comes as little surprise, but the continued favorable treatment under democracy may seem curious. The harsh treatment levied on heavy industry was very unexpected. Finally, the importance of environmental factors is especially appropriate since these factors may be capturing unmeasured damages.

This empirical analysis can easily be applied to other environmental topics in the transitional economies of Central and Eastern Europe, where environmental protection efforts have significantly changed. Nevertheless, the Czech Republic is an excellent case to examine because of the stark contrast between the communist and democratic regimes. Presumably, empirical analysis of other transitional economies, such as Hungary and Poland, where the contrast between political regimes is more subtle, would demand a greater differentiation of political change and lead to less clear results.

\section{BIBLIOGRAPHY}

Albrecht, Catherine. "Environmental Policies and Politics in Contemporary Czechoslovakia." Studies in Comparative Communism 20 (1987): 291-302.

Atlee, Tom. "Notes on Czechoslovakian Grassroots Activism: Findings and Recommendations." Unpublished manuscript. Prague: Czechoslovak Federal Ministry for the Environment, 1991.

Becker, Gary. "Crime and Punishment: An Economic Approach." Journal of Political Economy 78 (1968): 526-36.

Bíža, Ladislav. Deputy director, Department of Water Protection, Czech Ministry of the Environment. Private conversations in Prague, the Czech Republic, May 1993.

Coate, Malcolm, and McChesney, Fred. "Empirical Evidence on FTC Enforcement of the Merger Guidelines." Economic Inquiry 30 (1992): 277-293.

Cohen, Mark. "Optimal Enforcement Strategy to Prevent Oil Spills: An Application of a Principal-Agent Model with Moral Hazard." Journal of Law and Economics 30 (1987): 23-51.

Cohen, Mark. "Environmental Crime and Punishment: Legal/Economic Theory and Empirical Evidence on Enforcement of Federal Environmental Statutes." Journal of Criminal Law and Criminology 82 (1992): 1054-1108.

Cohen, Mark. "The Motives of Judges: Empirical Evidence from Antitrust Sentencing." International Review of Law and Economics 12 (1992): 12-30. 
Craswell, Richard, and Calfee, John. "Deterrence and Uncertain Legal Standards." Journal of Law, Economics, and Organization 2 (1986): 279-303.

Czech Ministry of the Environment. Environment of the Czech Republic: Evolution, Situations, and Trends to the End of 1989. Prague: Academia, 1990.

Czech Ministry of the Environment. Environment of the Czech Republic: State of the Environment 1992. Prague: Academia, 1992.

Deily, Mary, and Gray, Wayne. "Enforcement of Pollution Regulations in a Declining Industry." Journal of Environmental Economics and Management 21 (1991): 260-74.

Earnhart, Dietrich. "Public Influence on Environmental Protection Efforts: WaterRelated Citizen Correspondence in the Czech Republic.' Unpublished manuscript. Madison: University of Wisconsin-Madison, 1995.

Finsinger, J.; Hoehn, T.; and Pototschnig, A. "'The Enforcement of Product Liability Rules: A Two-Country Analysis of Court Cases.' International Review of Law and Economics 11 (1991): 133-48.

Goshko, Ana. "The Czech and Slovak Federal Republic in Transition." Congressional Research Service Report for Congress No. 92-52F. Washington, DC: Library of Congress, Congressional Research Service, December 27, 1991.

Greene, William. Econometric Analysis. New York: Macmillan, 1993.

Harbichová, Marketa. Legal counsel, Czech Ministry of the Environment, Department of Water Protection. Private conversations in Prague, the Czech Republic, May 1993.

Hubbard, K., and Selden, T. “Environmental Failures of Central Planning.' Society and Natural Resources 7 (1994): 169-80.

Hughes, Gordon. "Are the Costs of Cleaning Up Eastern Europe Exaggerated? Economic Reform and the Environment." Oxford Review of Economic Policy 7 (1992): 106-36.

Hunter, David, and Bowman, Margaret. "An Overview of the Environmental Community in the Czech and Slovak Federal Republic." Unpublished manuscript. Washington, D.C.: Center for International Environmental Law-United States, 1991.

Krupnick, Alan; Harrison, Ken; Nickell, Eric; and Toman, Michael. "The Value of Health Benefits from Ambient Air Quality Improvements in Central and Eastern Europe: An Exercise in Benefits Transfer." Environmental and Resource Economics 7 (1996): 307-32.

Maddala, G. S. Limited-Dependent and Qualitative Variables in Econometrics. New York: Cambridge University Press, 1983.

Nash, John. "To Make the Punishment Fit the Crime: A Theory and Statistical Estimation of A Multi-period Optimal Deterrence Model." International Review of Law and Economics 11 (1991): 101-10.

Peterson, D. J. Troubled Lands: The Legacy of Soviet Environmental Destruction. Boulder, Colo: Westview, 1993.

Polinsky, A. Mitchell, and Shavell, Steven. "Enforcement Costs and the Optimal Magnitude and Probability of Fines.' Journal of Law and Economics 35 (1992): 133-148.

Půlpán, Daniel. Inspector of the Czech Inspection-Water Management Division, 
Central Office. Private conversations in Prague, the Czech Republic, JanuaryJune 1993.

Shavell, Steven. "Risk-Sharing and Incentives in the Principal and Agent Relationship." Bell Journal of Economics 10 (1979): 55-73.

Shavell, Steven. Economic Analysis of Accident Law. Cambridge, Mass: Harvard University Press, 1987.

Snyder, Edward. "The Effect of Higher Criminal Penalties on Antitrust Enforcement." Journal of Law and Economics 33 (1990): 439-62.

World Bank. "Czech and Slovak Federal Republic Joint Environmental Study." Vols. 1, 2. Joint report of the Governments of Czechoslovakia, Czech and Slovak Republics, European Community, and United States. Washington, DC: World Bank Publications, 1992.

Ziegler, Charles. Environmental Policy in the USSR. Amherst: University of Massachusetts Press, 1987. 